\title{
15 The Teutonic Knights and their Attitude about Muslims: Saracens in the Latin Kingdom of Jerusalem and in the Baltic Region
}

\subsection{Introduction}

Research into the Teutonic Order has traditionally concentrated on its military activities in the Baltic region - in Prussia and Livonia - where its Knights waged a ruthless war against heathen tribes in an effort to strengthen Christianity in northern Europe. However, it is important to remember that the Teutonic Order began its military activities in the Latin Kingdom of Jerusalem, in the late twelfth century, battling Muslims. The extensive nature of these campaigns would gradually cripple the Latin Kingdom, contributing to its collapse in 1291.

The way the Teutonic Knights spoke of their enemies in the Baltic region indicates how they were affected by the constant fighting with Muslims in the Latin East. They described their enemies in the Baltic region as "Saracens" Muslims - a term that referred both to the Muslims as such and to their military capabilities.

This article will address different characteristics of the Teutonic Order in the Latin East and in the Baltic lands, as well as the way in which the Teutonic brethren viewed their enemies in the Baltic region. It will focus on how the campaigns in the Latin East influenced the way in which the Teutonic warriors referred to the heathen tribes in the Baltic region as Saracens, at a great remove from the Muslim military action in the Mediterranean Basin.

This article will emphasize the unique use of the term "Saracens" and the way it has affected the activities of the Teutonic Order upon moving its fighting from the Latin East to the Baltic region. This term, Saracens, became increasingly common when relating to the Teutonic enemies in the Baltic region as the enemies of Christianity, like the Muslim struggling against the Crusaders in the eastern Mediterranean basin.

During the twelfth century, the Crusaders were competing with the local Muslim population in the Latin East. This population had survived the first period of fighting and had maintained a presence within the Kingdom's territories since 1099. The Crusaders' toleration of the Muslim population, along with the economic, agricultural, and trade relations they developed with Muslims, 
came to an end when Muslim resistance increased in the eastern parts of the Mediterranean Basin - Egypt and Syria - during the second half of the twelfth century. ${ }^{1}$ With the rise of Saladin and the development of a more powerful Muslim army, the Crusaders came under consistent attack for a decade, beginning in 1177 in Montgisard near Rama (Ramla) and ending with the great defeat at the Battle of Hattin in July 1187.2 This battle marked the final stage of the first kingdom: Following this defeat the Crusader cities quickly fell into Muslim hands. ${ }^{3}$ Only with the Third Crusade of 1191, followed by the alliance of European warriors under King Richard I (Lionheart), was the Latin Kingdom recovered, creating a new Crusader entity in the coastal region, at a remove from Jerusalem, which remained under Muslim rule, with the exception of brief periods during the mid-thirteenth century. ${ }^{4}$

In 1197, in the wake of a Crusade known as the "German Crusade", led by German warriors who had arrived from Southern Italy, there was a renewed effort to re-conquer the Latin Kingdom. These warriors had fought in the Siege of Toron (Tibnin), contributing to the occupation of the coastal cities of Sidon and Beirut. ${ }^{5}$ The warriors who had remained in the Kingdom established the Teutonic Military Order in $1198 .^{6}$ This new military order joined the Hospitallers and the Templars, well-known military organizations that had been fighting the Muslims since the twelfth century. ${ }^{7}$ Did this unstable political and military situation influence the Teutonic Order's subsequent history and tradition? This question and related assumptions form the basis of this article. I will present the history of the Teutonic Order in the Latin East in the light of its struggle with the Muslims. I will also attempt to explain how these campaigns contributed to the Order's later military approach to its Teutonic enemies in Northern Europe, specifically the Prussians and Livonians. What did the Teutonic warriors adopt and absorb in the Latin East that allowed them to increase their standing in their future endeavours in other areas of Europe where they ruled and fought? These will be compared and explained in the next part of this article.

1 Runciman 1952, 403-435; Tyerman 2006, 336-341.

2 The Chronicle of Ibn al-Athìr, 253-324.

3 Chronique d'Ernoul, 167-171; Herde 1966, 1-50.

4 Prawer 1975, 69-99; Richard 1979, 185-199.

5 L'Estoire de Eracles, 227-228; Humphreys 1977, 106-110.

6 Favreau 1974, 64-66.

7 Riley-Smith 1967, 32-59; Barber 1994, 6-37. 


\subsection{Struggling against the Saracens in the Latin Kingdom of Jerusalem}

Beginning with the Fifth Crusade to Egypt in 1218-1221, the Teutonic Order participated in all the major campaigns against Muslims in the Latin Kingdom's territory and the surrounding area, alongside the other military orders and the Crusader nobility. ${ }^{8}$ The fighting in the Nile Delta in Egypt ended in defeat. Thirty Teutonic Knights were killed on the battlefield at the Battle of Damietta. ${ }^{9}$ Despite the defeat in Egypt, the Teutonic Knights won the recognition and admiration of the German nobility who participated in the Siege of Damietta. For their contribution to the battle in Egypt, they received grants and property in northern Europe, in France, and in the northern Holy Roman Empire. ${ }^{10}$ They also received assistance that allowed them to purchase land in western Galilee - in Mi'ilya and the surrounding area. ${ }^{11}$

The Sixth Crusade of 1228-1229, led by the Holy Roman Emperor Frederick II, brought changes to the Crusader movement's basic approach. Emperor Frederick II managed to regain many parts of the Holy Land through political negotiation, rather than by resorting to military force or directly confronting the Muslim troops. ${ }^{12}$ The Emperor's achievements, including the Crusaders gaining control of Jerusalem (albeit without the Temple Mount), as well as of many areas in Galilee, including Nazareth, Toron, and Hunin, led Church authorities to excommunicate him, bringing about a shift in the regional balance of power. ${ }^{13}$ The Teutonic Knights were among the few who supported Frederick II, accompanying him on his journey to Jerusalem. They also participated in the ceremony at the Church of the Holy Sepulchre to crown him king of Jerusalem. ${ }^{14}$ Pope Gregory IX attacked the Teutonic Order, attempting to remove them from positions of power and to deprive them of status. The Knights survived this crisis, both on the basis of the resistance mounted by the Order's magister, Hermann von Salza, and the prominent role the Order had played in the defence of the Latin Kingdom. Hermann von Salza wrote a letter to Pope Gregory IX, in which he described both the Crusade's achievements, including

8 Powell 1986, 160-161; Militzer 1999a, 33-36.

9 Gesta obsidionis Damiatae, 490; Huygens 1960, 120-122, 128-129.

10 Van Eickels 1998, 77-78; Krämer 2004, 246-247.

11 Mayer 1980, 210-213; Morton 2009, 53, 154.

12 Powell 1995, 263-264; Mastnak 2002, 148-152; Friedman 2011, 229-232, 238-239.

13 Huillard-Bréholles 1963, 92; Powell 1999, 19-26.

14 Coronatio Hierosolimitana 1229, no. 121; Hechelhammer 2004, 296-306. 
the construction of the Montfort Castle in Galilee, and the role the Order played in protecting the Frankish Kingdom..$^{15}$ In response, in 1230, the Pope appealed to all Christians to consolidate the Teutonic resistance and contribute to the maintenance of the castle in the Galilee as a boundary between Christianity and the infidels, and thus as a stronghold in the defence of Christianity from the attacks of the Saracens. The Pope also praised the Teutonic Knights as the period's "new Maccabees", who were chasing the Saracens from Holy Land. ${ }^{16}$

Saracens was the Crusaders' favoured term for their Muslim enemies. It was based on the word for the Middle Eastern wind (sharqi in Arabic) that swept across the eastern lands, bringing with it the nomadic Arab tribes from the Arabian desert that settled near the shores of Mediterranean, in the region of the Byzantine Empire. ${ }^{17}$ This unique term was a nod to the power Muslims wielded, but, above all, it was a term of resentment used by the Crusaders in the Latin East and in Europe to define all of their enemies, whether Muslims or pagan tribes, or even Christians who opposed the Pope and his emissaries. ${ }^{18}$

The unstable military situation in the Latin Kingdom, where battles were constantly being waged with the Muslims, lasted another decade. In 1244, following a series of conquests and ongoing efforts to strengthen the Latin Kingdom, a period of military decline set in, marked by the loss of territory. The Egyptians, who felt threatened by the Crusaders, who had allied with Muslim forces from Damascus and northern Syria, sought the support of the Khwarizmian tribes, who came from Central Asia to storm the Mediterranean region. ${ }^{19}$ The rival forces collided in the fields of the village Hirbiya (in French, La Forbie) in the area between Ascalon and Gaza, in the southern part of the Latin Kingdom. ${ }^{20}$

The Battle of La Forbie, which took place on 17 October 1244, resulted in the collapse of the Crusader army. The Egyptians attacked the Syrian Muslim forces dispersed throughout the area, leaving the Crusaders on their own against Egyptian forces and their allies. The Crusaders put up stiff resistance against the superior Muslim forces, but were finally defeated..$^{21}$ According to Crusader sources, 325 Hospitallers were killed, leaving only twenty-six survivors, 312 Templars died, with a mere thirty-three surviving, and 397 (of some

15 Kluger 1987, 78-82.

16 Tabulae Ordinis Theutonici, no. 72 (1230), 56-57.

17 Savvides 1997, 90-94.

18 Housley 2008, 210-223; Forey 1989, 4-5, 12-15.

19 Cahen 1962, 670-674; Humphreys 1977, 273-275.

20 Lotan 2012b, 57-58.

21 L'Estoire de Eracles 1859, 427-432. 
400) Teutonic warriors were killed. ${ }^{22}$ Many fighters tried to escape the battle, heading north toward Ascalon. Among them was the patriarch of Jerusalem, Robert of Nantes, who described being wounded and escaping the battlefield, which had been the scene of a defeat and a terrible slaughter. ${ }^{23}$

The terrible result of the battle and its aftermath underscores the superiority of the Muslim warriors in the Latin East. The Muslims had a different military strategy than the Crusaders, one better suited to the environment, the climate, and the terrain of the Latin East. They used light archers and moved quickly from site to site, whereas the Crusaders used heavy armour and bulky equipment. One medieval source described the Muslims' use of bows and arrows as "rain from Hell". 24

It is well known that the Crusader forces, including the military orders, studied the Muslim way of fighting and included groups of foreign soldiers among their troops, including Turcopoles, who were Christian Turks, and who also served in the Byzantine army. These were trained soldiers familiar with the realities of battle in the Frankish East, and with Muslim military methods and equipment. Their experience proved useful to the Crusaders in military confrontations with the Saracens. ${ }^{25}$ The Turcopoles are mentioned in Crusader sources for the significant service they rendered, helping the Teutonic Knights to organize their forces during battles. The Teutonic grand master's entourage included several Turcopoles, indicating the regard the Teutonic Knights, including their leadership, had for the Turcopoles and their military experience in fighting the Muslims in the Latin East. ${ }^{26}$ The Crusaders appear to have relied primarily on Christian forces, avoiding, where possible, alliances with Muslim troops. The experience of fighting alongside Muslim forces from Syria was a rare one, and was never repeated following the defeat at the Battle of La Forbie, in 1244 .

In 1260, the Mongols invaded Syria, threatening the Latin Kingdom in the process. The Kingdom's leaders assembled in Acre to discuss a Muslim appeal to join forces in an attack on the Mongols. The Crusader leaders wanted to support the Muslims, but the Teutonic grand master, Anno von Sangerhausen, insisted on avoiding military involvement, instead advocating maintaining the existent Crusader positions. He based his argument on a long-standing experience of the Saracens not keeping their promises to the Christians. The Crusad-

22 Rothelin 1859, 564.

23 Letter to the Prelates of France and England, 342.

24 Rothelin 1859, 544.

25 Harari 1997, 76-79.

26 Sterns 1969, 291-294. 
ers feared that the Muslims would invade the Kingdom, and turn against the Christians when the battle against the Mongols ended. The Teutonic grand master's opinion prevailed, eventually contributing to the Kingdom's survival following the defeat of the Mongols in Ayn Jalut and the Mamluk victory of 1260.27

It is important to point out that rather than attacking them, the Crusaders and the military orders developed a relationship with the Muslims in the Galilean villages and along the Mediterranean coast. The Teutonic Knights who had acquired lands and villages in the northern part of the Latin Kingdom of Jerusalem needed the local population, which was mostly Muslim, for agricultural produce and to acquire necessary goods. They also needed local support in their negotiations and communication with the local population. ${ }^{28}$ The Teutonic brethren used Arabic interpreters, some of them Muslim and others Eastern Christians (Syrians), who were familiar with the local culture of the Latin East. Some charters from that period make mention of the use of local interpreters at the Teutonic headquarters when purchasing land or signing contracts with the local Crusader nobility and other sections of the local population. ${ }^{29}$

The Crusaders enjoyed very little peace and stability from of the Battle of La Forbie in 1244 until the collapse of the Latin Kingdom in 1291. The Muslims had grown stronger, and the Crusaders were unable to repeat their twelfthcentury success. The Mamluks, led by Baybars, managed to upset the military balance in the region, conquering most of the Crusader fortifications in the 1260s - Nazareth, Arsor, Caesarea, Safed, Jaffa, Antioch, and finally, in 1271, the strongholds of the Hospitallers in Crac des Chevaliers and the Teutonic Order's Montfort Castle. The Frankish Kingdom remained a small entity, located close to the Muslim territories. The Kingdom survived only because peace agreements (hūdna in Arabic) were signed with the Muslims and Christians in Europe and in the Mediterranean Basin provided aid. ${ }^{30}$

In the end, this was not enough to ensure the Kingdom's survival. The Latin Kingdom's major city fell at the Battle of Acre, in May 1291. The Mamluk attack on Acre was a response to the Christians' treatment of a group of Muslims visiting the city. A group of Italian merchants attacked the foreign Muslims on the streets of Acre and killed them. This was in violation of the agreements signed with the Mamluks and was considered a serious provocation by the

27 Rothelin 1859, 637; Shirley 1999, 118-119; Jackson 1980, 502-503.

28 Riley-Smith 1972, 9-19; Attiya 1999, 206-209.

29 Röhricht 1893, no. 1399 (1274); no. 1435 (1280).

30 Marshall 1992, 25-26, 32; Thorau 1995, 69-88; Holt 1995, 69-88. 
Muslim world. The Crusaders sought peace with the Mamluks, but were rebuffed. 31

The fall of Acre is described in several medieval sources. One of them mentions the Teutonic resistance to the Muslim invaders and reactions to the brutal battle. This German medieval source identifies Konrad von Feuchtwangen as the Teutonic leader of Acre at the time. It is presumed that he led the retreat of the Teutonic Order from the city and its departure to Europe. Faced with a deteriorating city, the Teutonic leader chose this course, rather than allow his men to be killed for no reason. When the Teutonic Knights voiced their opposition, Konrad von Feuchtwangen promised to avenge the fall of Acre and the deaths of its Christians by killing as many infidels as possible in Prussia. He referred to them as Saracens. ${ }^{32}$

Udo Arnold rejects this version of events, presenting a number of contemporary medieval Frankish sources that mention Konrad's activities in that region. ${ }^{33}$ In addition, the fact that archaeological evidence indicates that the Teutonic compound in the north-eastern part of Acre was completely destroyed by fire, making it likely that most of the Teutonic brethren, including their leader, were killed in the 1291 battle with the Muslims, supports Arnold's perspective. ${ }^{34}$

It is well established that Konrad von Feuchtwangen understood the military situation of Muslims and Crusaders in the Latin East. In 1261, he served as the military order's treasurer in the Latin East, after which he was appointed Teutonic commander of the region. ${ }^{35}$ After serving in these positions, he joined the Teutonic Knights in Prussia, where he gained insight into the violent struggle in the Baltic region. Konrad von Feuchtwangen was a strong advocate of Teutonic settlement and resistance in Prussia, and, for the most part, objected to the persistent fighting in the Latin East. At the end of 1292, Konrad von Feuchtwangen was elected grand master of the Teutonic Order, a position he used to continue his efforts to shift the military order's focus from the Mediterranean Basin to the Baltic region of Prussia and in Livonia. ${ }^{36}$

31 Cronaca del Templare di Tiro, no. 244 (480), 199.

32 Ottokars österreichische Reimchronik, lines 51795-51823.

33 Arnold 1990, 22-40.

34 Pringle 2009, 134; Lotan 2012a, 33.

35 Tabulae Ordinis Theutonici, no. 121 (1261) 113, no. 126 (1273) 117; Wojtecki 1971, 45-48; Nieß 1998, 41-45.

36 Militzer 1999b, 77-78; Housley 1992, 326. 


\subsection{Struggling against the heathen enemies - the Saracens in the Baltic region}

While it strengthened its position in the Holy Land during the thirteenth century, the Teutonic Order was at a crossroads in northern Europe. In 1230, the Teutonic Knights invaded Prussia's Baltic region, north of Poland. This was in response to an appeal from Poland's leader, Konrad I of Mazovia. ${ }^{37}$ The Teutonic Order also received the approval of Emperor Fredrick II, who supported their mission in Prussia and, in 1226, gave them a charter known as the Golden Bull of Rimini. ${ }^{38}$ With a new battleground in Prussia, the Teutonic Order was poised to launch a new chapter in its history.

While it was only one of several military factions in the Latin Kingdom of Jerusalem, in Prussia the Teutonic Order was the primary faction engaging the heathen tribes opposing its advance into their lands. The Teutonic Knights fought a ruthless war against their infidel enemies, with fighting lasting until 1283, when the Teutonic Order completed its conquest of Prussia and established the Teutonic Ordensstaat. ${ }^{39}$

The Teutonic Order and the German rulers used a term acquired during the wars against the Muslims in the Latin East - Saracens - to define the heathen tribes fighting the Teutonic Order in Prussia and the German population in Livonia. The term expressed the revulsion the Christian warriors felt for their opponents. In 1211, the Roman Emperor Otto IV called the pagan warriors fighting the Christians in Livonia Saracens, describing them as enemies of Christianity. This same leader heaped praise on the members of the military order in Livonia known as the Brothers of the Sword, claiming that they were fighting a ruthless war against the Saracens from the north. 40

The description of the ruthless warfare in the Baltic region is primarily based on medieval Teutonic chronicles. One of the most important contemporary medieval sources is the Chronicon terrae Prussiae, written in 1326 by a priest who was a member of the Order - Peter von Dusburg. ${ }^{41}$ The heathen tribes in Prussia were known for their brutal behaviour, pillaging, and destruction of the Teutonic positions. ${ }^{42}$ Peter von Dusburg describes the heathen tribes

37 Johnson 1975, 569-571, 576-577; Labuda 1980, 299-316; Boockmann 1981, 70-93.

38 Hubatsch 1954, 46-53; Arnold 1976, 46.

39 Russel 1975, 5-22; Housley 1986, 266-280.

40 Seward 1972, 94; Mažeika 1994, 64.

41 Petrus de Dusburg 1965 [1861].

42 Peter von Dusburg, Chronik des Preussenlandes, 88; Favreau-Lilie 2000, 151-154; Matuzova 2001, 254-255; Mažeika 2009, 124-134 
with great distaste, depicting them as devoid of morality. ${ }^{43}$ They were also accused of being under Satan's command, fighting against the Christians on his behalf. ${ }^{44}$ Peter von Dusburg also described their pagan manners and their sacrificing of human victims, as well as their custom of mistreating the wounded and incinerating prisoners of war. The Teutonic Knights seem to have mimicked the heathen tribes' brutal behaviour. They murdered infidel warriors captured in battle, exiled women and children, and looted villages following battles. ${ }^{45}$

Another chronicle from the first half of the thirteenth century describes the Christianization of Livonia (roughly in the area of modern Latvia and Estonia) by a priest - Heinrich von Lettland (Henry of Livonia). ${ }^{46}$ The chronicler describes the cruel way in which infidels fought the Christian population when it settled in Livonia. He writes about Christians who went outside the fort at Üxküll to cultivate their land and were attacked by a group of heathen warriors. Several Christians were killed on the spot, and others suffered a cruel death through sacrifice. ${ }^{47}$

Another Christian source from the end of the thirteenth century, the Livländische Reimchronik, also describes the pagan tribes' cruelty. ${ }^{48}$ It mentions how the heathens tortured and sacrificed German prisoners to their gods before burning the bodies. ${ }^{49}$ The Germans' cruelty during battle was thus considered a response to the heathen warriors' behaviour on the battlefields of Prussia and Livonia. 50

Not only does the chronicle of Peter von Dusburg portray the cruelty of the fighting between the enemies in the Baltic region, it provides evidence of an unusual use of the term Saracens. The chronicler describes a Teutonic warrior named Hermann, called "Sarracenus", who was a member of the Teutonic Order defending the fortress of Königsberg (Kaliningrad). ${ }^{51}$ Why was he called Hermann Sarracenus? Did it symbolize his courage on the battlefield? Did he serve in the Latin Kingdom before moving to Prussia? The Teutonic chronicle does not answer these questions, but it is unlikely that this warrior was a Mus-

43 Peter von Dusburg, Chronik des Preussenlandes, 104.

44 Peter von Dusburg, Chronik des Preussenlandes, 344.

45 Peter von Dusburg, Chronik des Preussenlandes, 86; Urban 1981, 59.

46 Heinrich von Lettland, Chronicon Livoniae.

47 Bradbury 1961, 52.

48 Meyer 1876.

49 The Livonian Rhymed Chronicle, no. 759, 12; no. 1416, 21; no. 1665, 24.

50 The Livonian Rhymed Chronicle, no. 1519, 22; no. 1799, 25-26; no. 2363, 33-34; no. 3351, 46; Ghosh 2012, 94-98.

51 Peter von Dusburg, Chronik des Preussenlandes, 206. 
lim who joined the Teutonic Order and continued his military service in Prussia. There is no evidence of that ever happening.

There are other references to Muslims in the chronicle of Peter von Dusburg, and to the fighting against the Saracens in the Latin Kingdom of Jerusalem. He describes the heroic Teutonic battle against the Muslims in Acre in 1291, where many of the Teutonic warriors were killed. After the defeat in Acre and the loss of the Holy Land, Peter von Dusburg wrote a lament (Klage in German) about the fall of the Holy Land to the Muslims and the hard feelings it aroused. ${ }^{52}$ He also described in exaggerated terms a military campaign in 1300 on the eastern shores of the Mediterranean. The Crusaders, encouraged by the Mongols, attempted to re-conquer the Holy Land and recover their positions in the Latin Kingdom, but failed. He suggested that the fighting began in Armenia and continued along the coast of the Mediterranean up to Gaza. He also wrote that the Christians chased the Muslims south to the Egyptian border, killing 200,000 Muslim warriors. 53

After moving its headquarters from the Latin Kingdom to Venice, and then, in 1309, to Marienburg in Prussia, the Teutonic Order's military focus was on the Baltic region. The anger and the desire for revenge meant the continuing destruction of the infidel tribes and the exile of survivors to Lithuania, far away from Prussia. 54

The infidel population continued to live in Lithuania until 1386. Therefore, it became a favourite destination for the Teutonic Knights and the other European knights and nobles (mostly from France and England) that went on expeditions to demonstrate their knightly virtues. These journeys to the Baltic region were known by a unique term - Reisen. In these campaigns, the Christians continued to call their enemies Saracens, and Lithuania was called the land of the Saracens. 55

The war against the Lithuanians continued even after the majority of the population had converted to Christianity. The last battle fought in the fields of Tannenberg (Grunwald) in 1410 determined the Teutonic Order's fate in Prussia. The military order fought united Polish and Lithuanians forces, which had the support of numerous mercenaries and East European soldiers. The battle ended with the death of Teutonic Grand Master Ulrich von Jungingen and the military retreat of the remaining Teutonic warriors to their strongholds in Prus-

52 Peter von Dusburg, Chronik des Preussenlandes, 516.

53 Peter von Dusburg, Chronik des Preussenlandes, 520. See Schein 1979, 810-811.

54 Carsten 1956, 5-88; Burleigh 1984, 1-9.

55 Paravicini, 1, 1989, 118-130; Urban 1994, 520-526; Murray 2010, 416-420; Housley 1986, 272. 
sia. ${ }^{56}$ According to the Teutonic Order, they were delivered this harsh defeat by Saracens from Lithuania and elsewhere in Eastern Europe. ${ }^{57}$

Surprisingly, this term was still in use more than one hundred years after the Teutonic Order was driven from the East and had retreated from the Baltic region. The intensity with which the Muslims fought and the influence they had on events, even in the post-Crusade era, left its mark. The Teutonic Order subsequently used a term it had originally applied to Muslim warriors - Saracens - during its military campaigns in the Latin Kingdom of Jerusalem in the Baltic region. The term Saracens, originally used for the warriors of the East, became the term used to identify all enemies of Christianity and Christian hegemony in the Baltic region, whether Prussians, Lithuanians, or even Christians who opposed the Teutonic Order and its rule in the fifteenth century.

There is evidence in several medieval sources from the Baltic region supporting the hypothesis that the Teutonic Order transposed the term Saracens from the Latin East to the Baltic region. There were only descriptive chronicles or charters written by Teutonic brethren, mostly priests, serving in the Military Order or parts of the Teutonic headquarters' associates. The people in the heathen tribes were illiterate, therefore they did not leave recorded descriptions, and if they did these were lost and had never been exposed. The only evidence we have regarding the Baltic military activities and the clash between the two major forces derives from the Teutonic Knights' chronicles written by clergy members of the Military Orders, but this information is prejudiced and onedirectional.

The term Saracens had brought attention to the Other by way of differentiation and alienation. Dealing with Otherness prompted in the Teutonic brethren a sense of uniqueness and difference from the banished heathen tribes. The Teutonic descriptions allow us to estimate that the Teutonic warriors and clergy felt a sense of disgust and hesitation towards the pagans surrounding them in the Baltics. These lead to descriptions and harsh stereotypes against these ruthless enemies. With this term, the Teutonic Order pronounced its revulsion of its pagan enemies and their cruel resistance in battle.

These issues transferred from the Latin East were not reinforced in the extremely long campaign in the Baltic region. In this sense, adopted images and designations were used as another way of describing the enemies of the Christian faith, without unwillingness to connect them and to build the path towards acceptance of the Other, the cruel rivals of the Teutonic Order in Prussia and Livonia. This term was applied to any powerful, unwavering, and un-

56 Militzer 2005, 143-146; Boockmann 1966, 84-88.

57 Chronique du religieux de Saint-Denys, 453; Enguerran de Monstrelet, 455. 
compromising enemy, as well as to the heathen tribes that opposed Christianity and Church authorities.

The memory of their resolute enemies from the Latin East remained tangible for the Teutonic Order, and it influenced their military and political activities in the Baltic region. This was yet another way that the Crusade movement left its mark on European warriors in their struggle against their enemies in the outlying regions of medieval Europe.

\section{Bibliography}

\section{Primary sources}

Bradbury, James A. (Trans.). The Chronicle of Henry of Livonia. Madison: University of Wisconsin Press, 1961.

Chronique d'Ernoul = Mas Latrie, Louis de (Ed.). Chronique d'Ernoul et de Bernard le Trésorier. Paris: J. Renouard, 1871.

Chronique du religieux de Saint-Denys = Hirsch, Theodor, Max Töppen, and Ernst Strehlke (Eds.). "Chronique du religieux de Saint-Denys." Scriptores Rerum Prussicarum. Vol. 3. Leipzig: S. Hirzel, 1866. 453-454.

Coronatio Hierosolimitana 1229 = Weiland, Ludwig (Ed.). Coronatio Hierosolimitana 1229, Monumenta Germaniae Historica, Constitutiones et Acta Publica Imperatorum et Regum. Vol. 2. Hannover: Hahn, 1896.

Cronaca del Templare di Tiro = Minervini, Laura (Ed.). Cronaca del Templare di Tiro (12431314), la caduta degli stati crociati nel racconto di un testimone oculare. Napoli: Liguori, 2000.

Enguerran de Monstrelet $=$ Hirsch, Theodor, Max Töppen, and Ernst Strehlke (Eds.).

“Enguerran de Monstrelet." Scriptores Rerum Prussicarum. Vol. 3. Leipzig: S. Hirzel, 1866. 455-458.

Gesta obsidionis Damiatae $=$ Holder-Egger, Oswald (Ed.). "Iohannes Codagnelli Gesta obsidionis Damiatae 1217-1219." Monumenta Germaniae Historica, Scriptores in Folio. Vol. 31. Hannover: Hahn, 1903.

Heinrich von Lettland, Chronicon Livoniae = Arbusow, L., and A. Bauer (Eds.). Heinrici Chronicon Livoniae. Monumenta Germaniae Historica, Scriptores rerum Germanicarum. Vol. 31. Hannover: Hahn, 1955.

Hubatsch, Walter. Quellen zur Geschichte des Deutschen Ordens. Göttingen: "Musterschmidt" Wissenschaftlicher Verlag, 1954.

Huillard-Bréholles, Jean (Ed.). Historia Diplomatica Friderici Secundi. Vol. 3. Torino: Bottega d'Erasmo, 1963 [1852].

Huygens, Robert B. C. Lettres de Jacques de Vitry (1160/1170-1240), éveque de Saint Jean d'Acre. Leiden: Brill, 1960.

L'Estoire de Eracles = "L'Estoire d'Eracles Empereur et la Conqueste de la Terre d'Outremer." Recueil des Historiens des Croisades Historiens Occidentaux (RHC Occ). Vol. 2. Paris: Imprimerie Impériale, 1859. 
Letter to the Prelates of France and England = Luard, Henry R. (Ed.). Letter to the Prelates of France and England, Matthew Paris, Chronica Majora. Rolls Series 57.4. London: Longman, 1872-1883. 337-344.

Meyer, Leo (Ed.). Livländische Reimchronik. Paderborn: Schöningh, 1876.

Ottokars österreichische Reimchronik = Seemüller, Joseph (Ed.). Ottokars österreichische Reimchronik nach den Abschriften Franz Lichtensteins. Monumenta Germaniae Historica, Deutsche Chroniken. 2 vols. Zürich: Weidmann, 1974.

Paravicini, Werner. Die Preußenreisen des europäischen Adels. Vol. 1. Sigmaringen: Thorbecke, 1989.

Peter von Dusburg, Chronik des Preussenlandes = Scholz, Klaus, and Dieter Wojtecki (Trans.). Peter von Dusburg, Chronik des Preussenlandes. Darmstadt: Wissenschaftliche Buchgesellschaft, 1984.

Petrus de Dusburg, “Chronicon terrae Prussiae." Scriptores Rerum Prussicarum. Vol. 1. Ed. Max Töppen. Leipzig, 1861; repr. Frankfurt am Main: Minerva, 1965. 1-219.

Röhricht, Reinhold (Ed.). Regesta Regni Hierosolymitani 1097-1291. Innsbruck: Libraria Academica Wagneriana, 1893.

Rothelin 1859 = "Continuation de Guillaume de Tyr de 1229 à 1261, dite du manuscript de Rothelin." Recueil des Historiens des Croisades Historiens Occidentaux (RHC Occ). Vol. 2. Paris: Imprimerie Impériale, 1859.

Shirley, Janet (Trans.). Crusader Syria in the Thirteenth Century, The Rothelin Continuation of the History of William of Tyre with Part of the Eracles or Acre Text. Aldershot: Ashgate, 1999.

Tabulae Ordinis Theutonici $=$ Strehlke, Ernst (Ed.). Tabulae Ordinis Theutonici ex tabularii regii Berolinensis codice potissimum. Berlin: Weidmann, 1869; repr. Toronto: Prelum Academicum Universitatis Torontonensis, 1975.

The Chronicle of Ibn al-Athïr = Richards, Donald S. (Trans.). The Chronicle of Ibn al-Athïr for the Crusading Period from al-Kāmil fi'l-tarīkh. The Years 541-589/1146-1193. The Age of Nur al-Din and Saladin, Part 2. Aldershot: Ashgate, 2007.

The Livonian Rhymed Chronicle $=$ Smith, Jerry Christopher, and William. L. Urban (Trans.). The Livonian Rhymed Chronicle. Bloomington: Indiana University, 1977.

\section{Literature}

Arnold, Udo. “Der Deutsche Orden und die Goldbulle von Rimini.” Preußenland 14 (1976): 44-48.

Arnold, Udo. "Deutschmeister Konrad von Feuchtwangen und die 'preußische Partei' im Deutschen Orden am Ende des 13. und zu Beginn des 14. Jahrhunderts.” Aspekte der Geschichte. Festschrift für Peter Gerrit Thielen zum 65. Geburtstag. Göttingen: MusterSchmidt, 1990. 22-40.

Attiya, Hussein M. "Knowledge of Arabic in the Crusader States in the Twelfth and Thirteenth Centuries." Journal of Medieval History 25.3 (1999): 203-213.

Barber, Malcolm. The New Knighthood. A History of the Order of the Temple. Cambridge: Cambridge University Press, 1994.

Boockmann, Hartmut. "Zu den politischen Zielen des Deutschen Ordens in seinen Auseinandersetzungen mit dem preußischen Ständen." Jahrbuch für die Geschichte Mittel- und Ostdeutschlands 15 (1966): 84-88. 
Burleigh, Michael. Prussian Society and the German Order: An Aristocratic Corporation in Crisis c. 1410-1466. Cambridge: Cambridge University Press, 1984.

Cahen, Claude. "The Turks in Iran and Anatolia before the Mongol Invasions." A History of the Crusades, The Later Crusades, 1189-1311. Vol. 2. Eds. Robert L. Wolff and Harry W. Hazard. Madison: University of Wisconsin Press, 1969. 661-691.

Carsten, Francis. L. The Origins of Prussia. Oxford: Clarendon Press, 1954.

Favreau, Marie-Louise. Studien zur Frühgeschichte des Deutschen Ordens. Stuttgart: E. Klett, 1974.

Favreau-Lilie, Marie-Louise. "Mission to the Heathen in Prussia and Livonia: The Attitudes of the Religious Military Orders toward Christianization." Christianizing Peoples and Converting Individuals. Eds. Guyda Armstrong and Ian N. Wood. Turnhout: Brepols, 2000. 147-154.

Forey, Alan, "The Military Orders and the Holy War against Christians in the Thirteenth Centuries." English Historical Review 104 (1989): 1-24.

Friedman, Yvonne. "Peacemaking: Perceptions and Practices in the Medieval Latin East." The Crusades in the Near East. Ed. Conor Kostick. London: Routledge, 2011. 229-257.

Ghosh, Shami. "Conquest, Conversion, and Heathen Customs in Henry of Livonia's Chronicon Livoniae and the Livländische Reimchronik." Crusades 11 (2012): 87-108.

Harari, Yuval. "The Ministry Role of the Frankish Turcopoles: A Reassessment." Mediterranean History Review 12.1 (1997): 75-116.

Hechelhammer, Bodo. Kreuzzug und Herrschaft unter Friedrich II. Handlungsräume von Kreuzzugspolitik (1215-1230). Ostfildern: Thorbecke, 2004.

Herde, Peter. “Die Kämpfe bei den Hörnern von Hittin und der Untergang des Kreuzritterheeres (3. and 4. Juli 1187). Eine historisch-topographische Studie.” Römische Quartalschrift für christliche und Altertumskunde und Kirchengeschichte 61 (1966): 1-50.

Holt, Peter M. Early Mamluk Diplomacy (1260-1290). Leiden: Brill, 1995.

Housley, Norman. The Avignon Papacy and the Crusades, 1305-1378. Oxford: Clarendon Press, 1986.

Housley, Norman. The Later Crusades, 1274-1580. Oxford: Oxford University Press, 1992.

Housley, Norman. Fighting for the Cross, Crusading to the Holy Land. New Haven: Yale University Press, 2008.

Humphreys, R. Stephen. From Saladin to the Mongols, The Ayyubids of Damascus, 11931260. Albany: State University of New York Press, 1977.

Jackson, Peter. "The Crisis in the Holy Land in 1260.” English Historical Review 95 (1980): 481-513.

Johnson, Edgar N. "The German Crusade on the Baltic." A History of the Crusades. Vol. 3. Ed. Harry W. Hazard. Madison: University of Wisconsin Press, 1975. 545-585.

Kluger, Helmuth. Hochmeister Hermann von Salza und Kaiser Friedrich II. Marburg: N. G. Elwert, 1987.

Krämer, Thomas. “Der Deutsche Orden im heutigen Frankreich.” L'Ordine Teutonico nel Mediterraneo. Atti del Convegno internazionale di studio Torre Alemanna (Cerignola)Mesagne - Lecce 16-18 ottobre 2003. Ed. Hubert Houben. Galatina: M. Congedo, 2004. 237-276.

Labuda, Gerard. "Die Urkunden über die Anfänge des Deutschen Ordens in Kulmerland und in Preußen in den Jahren 1226-1243." Die geistlichen Ritterorden Europas. Eds. Josef Fleckenstein and Manfred Hellmann. Sigmaringen: J. Thorbecke, 1980. 299-316.

Lotan, Shlomo. “Governing the Teutonic Order from 'Outremer' - The Teutonic Headquarters Competing in the Last Era of the Latin Kingdom of Jerusalem." Herrschaft, Netzwerke, 
Brüder des Deutschen Ordens in Mittelalter und Neuzeit. Ed. Klaus Militzer. Weimar: VDG, 2012a. 25-38.

Lotan, Shlomo. "The Battle of La Forbie (1244) and its Aftermath - Re-examination of the Military Orders Involvement in the Latin Kingdom of Jerusalem in the mid-Thirteenth Century." Ordines Militares. Yearbook for the Study of the Military Orders 17 (2012b): 53-67.

Marshall, Christopher. Warfare in the Latin East, 1192-1291. Cambridge: Cambridge University Press, 1992.

Mastnak, Tomaz. Crusading Peace, Christendom, the Muslim World and Western Political Order. Berkeley: University of California Press, 2002.

Matuzova, Vera I. "Mental Frontiers: Prussians as Seen by Peter von Dusburg." Crusade and Conversion on the Baltic Frontier 1150-1500. Ed. Alan V. Murray. Aldershot: Ashgate, 2001. 253-260.

Mayer, Hans E. "Die Seigneurie de Joscelin und der Deutsche Orden." Die geistlichen Ritterorden Europas. Eds. Josef Fleckenstein and Manfred Hellmann. Sigmaringen: Thorbecke, 1980. 171-216.

Mažeika, Rasa. "Of Cabbages and Knights: Trade and Trade Treaties with the Infidel on the Northern Frontier, 1200-1390." Journal of Medieval History 20 (1994): 63-76.

Mažeika, Rasa. "Violent Victims? Surprising Aspects of the Just War Theory in the Chronicle of Peter von Dusburg." The Clash of Cultures on the Medieval Baltic Frontier. Ed. Alan V. Murray. Aldershot: Ashgate, 2009. 123-140.

Militzer, Klaus. Von Akkon zur Marienburg, Verfassung, Verwaltung und Sozialstruktur des Deutschen Ordens 1190-1309. Marburg: Elwert, 1999a.

Militzer, Klaus. "From the Holy Land to Prussia: The Teutonic Knights between Emperors and Popes and their Policies until 1309." Mendicants, Military Orders, and Regionalism in Medieval Europe. Ed. Jürgen Sarnowsky. Aldershot: Ashgate, 1999b. 71-81.

Militzer, Klaus. Die Geschichte des Deutschen Ordens. Stuttgart: Kohlhammer, 2005.

Morton, Nicholas E. The Teutonic Knights in the Holy Land 1190-1291. Woodbridge: Boydell Press, 2009.

Murray, Alan V. "The Saracens of the Baltic: Pagan and Christian Lithuanians in the Perception of English and French Crusades to Late Medieval Prussia." Journal of Baltic Studies 41.4 (2010): 413-429.

Nieß, Ulrich. "Konrad von Feuchtwangen.” Die Hochmeister des Deutschen Ordens 11901194. Ed. Udo Arnold. Marburg: N. G. Elwert, 1998. 41-45.

Powell, James M. Anatomy of a Crusade 1213-1221. Philadelphia: University of Pennsylvania Press, 1986.

Powell, James M. "Frederick II and the Muslims: The Making of an Historiographical Traditon." Iberia and the Mediterranean World of the Middle Ages. Ed. Larry J Simon. Leiden: Brill, 1995. 261-269.

Powell, James M. "Patriarch Gerold and Frederick II: The Matthew Paris Letter." Journal of Medieval History 25.1 (1999): 19-26.

Prawer, Joshua. Histoire du Royaume Latin de Jérusalem. Vol. 2. Trans. G. Nahun. Paris: Centre national de la recherche scientifique, 1975.

Pringle, Denys. The Churches of the Crusader Kingdom of Jerusalem: A Corpus. Vol. 4. The Cities of Acre and Tyre. Cambridge: Cambridge University Press, 2009.

Richard, Jean. The Latin Kingdom of Jerusalem. Vol. 11 A. Trans. Janet Shirley. Amsterdam: North-Holland Pub., 1979. 
Riley-Smith, Jonathan. The Knights of St. John in Jerusalem and Cyprus 1050-1310. London: Macmillan, 1967.

Riley-Smith, Jonathan. "Some Lesser Officials in Latin Syria." English Historical Review 87 (342) (1972): 1-26.

Runciman, Steven. A History of the Crusades. The Kingdom of Jerusalem and the Frankish East 1100-1187. Vol. 2. Cambridge: Cambridge University Press, 1952.

Russel, Frederick. The Just War in the Middle Ages. Cambridge: Cambridge University Press, 1975.

Savvides, Alexis G. C. "Some Notes on the Terms Agarenoi, Ismaelitai and Sarakenoi in Byzantine Sources.” Byzantion 67 (1997): 89-96.

Schein, Sylvia. "Gesta Dei per Mongolos 1300. The Genesis of a Non-Event.” English Historical Review 94 (1979): 805-819.

Seward, Desmond. The Monks of War. London: Eyre Methuen, 1972.

Sterns, Indrikis. The Statutes of the Teutonic Knights. A Study of Religious Chivalry. Philadelphia: University of Pennsylvania, 1969.

Thorau, Peter. The Lion of Egypt, Sultan Baybars I and the Near East in the Thirteenth Century. London: Longman, 1987.

Tyerman, Christopher. God's War. A New History of the Crusades. Cambridge, MA: Belknap Press, 2006.

Urban, William. The Livonian Crusade. Washington, DC: University Press of America, 1981.

Urban, William. "The Teutonic Knights and the Baltic Chivalry." The Historian 56.3 (1994): 519-530.

Van Eickels, Klaus. "Knightly Hospitallers or Crusading Knights? Decisive Factors for the Spread of the Teutonic Knights in the Rhineland and the Low Countries, 1216-1300." The Military Orders, Welfare and Warfare. Vol. 2. Ed. Helen Nicholson. Aldershot: Ashgate, 1998. 75-80.

Wojtecki, Dieter. Studien zur Personengeschichte des Deutschen Ordens im 13. Jahrhundert. Wiesbaden: Steiner Franz, 1971. 